\title{
Pemberian Ekstrak Floret Pisang Raja (Musa $x$ paradisiaca) Mencegah Penurunan Kadar Superoksida Dismutase (SOD) pada Hati Mencit (Mus musculus) BALB/c dengan Aktivitas Fisik Berlebih
}

\author{
${ }^{1}$ Okky Irtanto, ${ }^{2}$ Alex Pangkahila, ${ }^{3}$ IGM Aman
}

\author{
${ }^{1}$ Program Pascasarjana Anti-Aging Medicine \\ ${ }^{2}$ Departemen Andrologi dan Seksologi \\ ${ }^{3}$ Departemen Farmakologi \\ Fakultas Kedokteran Universitas Udayana Denpasar \\ E-mail: okkyirtanto@yahoo.com
}

\begin{abstract}
Overtraining accelerates aging due to the excessive production of free radicals that can cause oxidative stress. Banana floret extract contains bioactive compounds with antioxidant capacity which can increase the body's defence to deal with the oxidative stress by increasing the level of superoxide dismutase (SOD). This study was aimed to prove that the banana (Musa x paradisiaca) floret extract could prevent the decrease of superoxide dismutase (SOD) levels in overtraining-induced mice (Mus musculus) BALB/c liver. This was a true experimental study with the post-test only control group design. Subjects were 36 male mice (Mus musculus), BALB/c strain, 12 weeks old, weighing 20-22 g, which were divided into two groups with 18 mice each. The control group (P0) was treated with a placebo of 1 ml aquadest and overtrained for 14 days meanwhile the treatment group (P1) was treated with banana (Musa $x$ paradisiaca) floret extract of $400 \mathrm{mg} / \mathrm{kgBW} / \mathrm{day}$ and overtrained for 14 days. The results showed that after 14-day treatment, the mean SOD level in the liver tissue of the P0 group was $568.82 \pm 9.558 \mathrm{U} / \mathrm{mg}$ protein whereas in the P1 group was $588.37 \pm 10.629 \mathrm{U} / \mathrm{mg}$ protein $(P<0.01)$. The t-independent test showed a t value of -5.804 and a $P$ value of 0.000 which indicated that after treatment, the levels of SOD in liver tissue of both groups were significantly different. Conclusion: Banana (Musa x paradisiaca) floret extract could prevent the decrease of superoxide dismutase (SOD) levels in the liver tissue of overtraining-induced mice (Mus musculus) BALB/c.
\end{abstract}

Keywords: banana floret, SOD, liver, overtraining

\begin{abstract}
Abstrak: Aktivitas fisik berlebih mempercepat penuaan karena meningkatkan produksi radikal bebas yang dapat menyebabkan stres oksidatif. Ekstrak floret pisang mengandung senyawa bioaktif dengan kapasitas antioksidan yang dapat meningkatkan pertahanan tubuh dalam menghadapi stres oksidatif melalui peningkatan kadar superoksida dismutase (SOD). Penelitian ini bertujuan untuk membuktikan bahwa pemberian ekstrak floret pisang raja (Musa $x$ paradisiaca) dapat mencegah penurunan kadar SOD pada hati mencit (Mus musculus) BALB/c dengan aktivitas fisik berlebih. Jenis penelitian ialah eksperimental murni dengan post test only control group design. Subjek penelitian ialah 36 ekor mencit (Mus Musculus) $\mathrm{BALB} / \mathrm{c}$, jantan, berumur 12 minggu, berat badan 20-22 gr, yang dibagi menjadi dua kelompok masing-masing berjumlah 18 ekor mencit. Kelompok kontrol (P0) diberikan plasebo berupa aquadest sebanyak $1 \mathrm{ml}$ dengan aktivitas fisik berlebih selama 14 hari, dan kelompok perlakuan (P1) diberikan ekstrak floret pisang raja (Musa x paradisiaca) dosis 400 $\mathrm{mg} / \mathrm{kgBB}$ mencit per hari dicampur aquadest hingga $1 \mathrm{ml}$ dengan aktivitas fisik berlebih selama 14 hari. Hasil penelitian menunjukkan rerata kadar SOD jaringan hati pada kelompok kontrol (P0) sesudah perlakuan (post-test) ialah 568,82 $\pm 9,558 \mathrm{U} / \mathrm{mg}$ protein, sedangkan pada

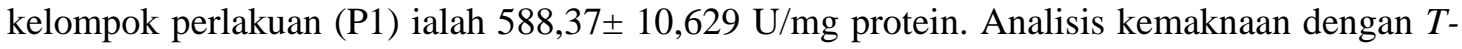


Independent mendapatkan nilai $t=-5,804$ dan nilai $P=0,000$ yang menunjukkan bahwa sesudah perlakuan (post-test), kadar SOD jaringan hati pada kedua kelompok berbeda sangat bermakna. Simpulan: Ekstrak floret pisang raja (Musa $x$ paradisiaca) dapat mencegah penurunan kadar SOD pada hati mencit (Mus musculus) BALB/c dengan aktivitas fisik berlebih.

Kata kunci: floret pisang raja, SOD, hati, aktivitas fisik berlebih

Penuaan merupakan proses yang dialami oleh setiap mahluk hidup yang dapat mengurangi kualitas hidup seseorang. Pada penuaan terjadi kerusakan struktur dan fungsi molekul, sel, serta organ dari suatu organisme dengan penyebab multifaktorial. ${ }^{1}$ Saat ini, salah satu penjelasan untuk dasar mekanis penuaan ialah "teori radikal bebas" yang mendalilkan bahwa penuaan dan penyakit terkait merupakan konsekuensi dari kerusakan akibat induksi radikal bebas makromolekul seluler dan ketidakmampuan untuk mengimbangi perubahan ini oleh pertahanan anti-oksidan endogen. ${ }^{2}$

Reaksi degenerasi redoks dari sistem biologi pasti menghasilkan reactive oxygen species (ROS) dan derivatnya. Stres oksidatif adalah hasil ketidakseimbangan dalam homeostasis pro-oksidan/antioksidan yang membawa ROS toksik. ${ }^{3}$ Radikal bebas dapat diproduksi selama metabolism aerobik selular dan memiliki kunci utama sebagai mediator regulasi proses sinyaling. Latihan fisik berlebih menyebabkan peningkatan stres oksidatif, meskipun stimulus tersebut diperlakukan untuk meningkatkan regulasi pertahanan antioksidan endogen. ${ }^{4}$ Sistem antioksidan ini termasuk enzim antioksidan (superoksia dismutase/SOD, glutathione peroxidasel GPx dan katalase/CAT), golongan nutrisi antioksidan (misalnya: asam askorbat, tokoferol dan tocotrienol, karotenoid, glutation, dan asam lipoat), protein pengikat logam (misalnya, feritin, laktoferin, albumin, seruloplasmin) dan banyak antioksidan fitonutrien dalam berbagai macam makanan nabati. ${ }^{5}$

Dukungan pertahanan endogen dengan penambahan suplementasi oral antioksidan dapat mencegah atau mengurangi stres oksidatif selama aktivitas fisik berlebih. ${ }^{4}$
Sebuah faktor transkripsi sensitif redoks, nuclear factor-erythroid related factor-2 (Nrf2), merupakan regulator utama dari aktivasi transkripsi gen yang mengkode protein sitoprotektif. Banyak fitokimia chemopreventive diketahui mengaktifkan Nrf2 baik oleh oxidasi maupun modifikasi kovalen dari reseptor sitosolik Kelch-like ECH-associated protein (Keap1) atau melalui fosforilasi Nrf2. Setelah teraktivasi, Nfr2 bertranslokasi ke nukleus dan mengikat antioxidant response element yang berlokasi di daerah promotor gen yang mengkode protein sitoprotektif. ${ }^{6}$

Pisang merupakan tanaman asli Asia Tenggara termasuk Indonesia yang mudah dibudidayakan. ${ }^{7}$ Analisis fitokimia telah dilakukan terhadap beberapa bagian dari pohon pisang, namun floret (bagian bunga betina dari jantung pisang) pisang memiliki kadar fenolik yang lebih tinggi dibandingkan batang, daun dan bract (bagian bunga jantan jantung pisang). ${ }^{8}$ Dari uji yang dilakukan di Unit Laboratorium Fakultas Pertanian Universitas Udayana, analisis fitokimia bunga (floret) pisang raja, diperoleh kadar flavonoid 499,37 mg/100g quercetin equivalent, kadar total fenol $658,40 \mathrm{mg} / 100 \mathrm{~g}$ gallic acid equivalent, tannin 476,09 $\mathrm{mg} / 100 \mathrm{~g}$ tannic acid equivalent, saponin $132,98 \mathrm{mg} / 100 \mathrm{~g}$ quarcetin equivalent, dan kapasitas antioksidan 815,99 $\mathrm{mg} / \mathrm{L}$ gallic acid equivalent antioxidant capacity.

Ekstrak floret pisang merupakan sumber antioksidan alami dengan kandungan flavonoid yang cukup tinggi dan mudah ditemukan di Indonesia. Meskipun penelitian sebelumnya melaporkan bahwa floret pisang merupakan salah satu sumber antioksidan yang baik, namun belum ada penelitian yang melaporkan ekstrak floret pisang dapat menghambat 
penurunan kadar antioksidan endogen seperti SOD pada mencit yang mengalami stres oksidatif dengan aktivitas fisik berlebih.

\section{METODE PENELITIAN}

Penelitian ini bertujuan untuk membuktikan bahwa pemberian ekstrak floret pisang raja (Musa $x$ paradisiaca) dapat meningkatkan kadar enzim SOD hati pada mencit (Mus musculus) BALB/c dengan aktivitas fisik berlebih. Jenis penelitian ialah eksperimental murni dengan menggunakan post test only control group design. Subjek penelitian ialah 36 ekor mencit (Mus musculus) BALB/c, jantan, berumur 12 minggu, dengan berat badan 20-22 gr yang terbagi menjadi dua kelompok, masing-masing berjumlah 18 ekor mencit. Kelompok kontrol (P0) diberikan plasebo berupa aquadest sebanyak $1 \mathrm{ml}$ dengan aktivitas fisik berlebih selama 14 hari, sedangkan kelompok perlakuan (P1) diberikan ekstrak floret pisang raja (Musa $x$ paradisiaca) dosis $400 \mathrm{mg} / \mathrm{kgBB}$ mencit per hari dicampur aquadest hingga $1 \mathrm{ml}$ dengan aktivitas fisik berlebih selama 14 hari.

Dua puluh empat jam setelah perlakuan berakhir, keseluruhan kelompok mencit dieutanasi dengan cara dislokasi tulang leher untuk diambil organ hatinya. Organ hati kemudian diambil dan dicuci dengan phosphate buffer saline (PBS), ditiriskan dan ditimbang beratnya, kemudian dikemas dengan alufo dan disimpan di dalam freezer $\left(-20^{\circ} \mathrm{C}\right)$. Kadar SOD spesimen dianalisis menggunakan SOD assay kit dari perusahaan Biovision dengan merk Biovision.

\section{HASIL DAN BAHASAN}

Pada penelitian ini, mencit diberikan aktivitas fisik berupa perenangan hingga menyebabkan kondisi overtraining yang ditandai dengan kondisi kelelahan berupa mencit hampir tenggelam oleh karena menurunnya kekuatan otot, waktu reaksi, frekuensi gerakan, dan refleks. ${ }^{9}$ Aktivitas fisik berlebih (overtraining) diberikan setiap hari selama 14 hari. ${ }^{10}$
Ketika melakukan aktivitas fisik yang cukup berat (misalnya tes treadmil), terjadi peristiwa yang menyerupai fenomena iskemia-reperfusi dimana peningkatan penyediaan oksigen (oxygen supply) sering kali tidak mampu memenuhi kebutuhan oksigen (oxygen demand) yang disebut sebagai fase iskemia. Peningkatan penyediaan oksigen yg tinggi justru akan meningkatkan pembentukan radikal bebas oksigen bahkan bisa mencapai 10x lipat (fase reperfusi). Beberapa penelitian telah membuktikan bahwa aktivitas fisik yg berat dapat menyebabkan stres oksidatif dengan produksi radikal bebas oksigen meningkat secara bermakna. ${ }^{11}$ Penelitian juga telah membuktikan bahwa aktivitas fisik yang berat dapat menyebabkan stres oksidatif. ${ }^{12}$

Jumlah radikal bebas dan mekanisme adaptasi pada mencit meningkat secara bermakna, berkaitan dengan jumlah konsumsi oksigen. Radikal oksigen terbentuk oleh adanya reduksi oksigen yang tidak lengkap. Latihan fisik yang mendadak mengakibatkan peningkatan konsumsi oksigen sehingga terjadi peningkatan pembentukan radikal bebas. Peningkatan molekul ini terjadi juga dalam perpanjangan latihan serta latihan dengan intensitas yang tinggi, namun aktivitas fisik mampu mengadaptasi untuk mencegah efek berbahaya dari oksigen radikal bebas. ${ }^{13}$ Aktivitas fisik berlebih meningkatkan ROS dalam jaringan, dan 2-5\% oksigen yang dipakai dalam metabolisme tereduksi menjadi ion superoksid yang bersifat radikal bebas. Kondisi ini akan menyebabkan stres oksidatif. ${ }^{14}$ Hasil penelitian menyebutkan bahwa aktivitas fisik berlebih dapat menginduksi stres oksidatif, serta menurunkan aktivitas dan kadar SOD, glutation (GSH), dan katalase pada eritrosit. ${ }^{15}$

Hasil penelitian ini menunjukkan bahwa pemberian ekstrak floret pisang raja (Musa x paradisiaca) dapat meningkatkan kadar SOD jaringan hati yang menurun akibat aktivitas fisik berlebih. Hasil menunjukkan rerata kadar SOD jaringan hati pada kelompok kontrol (P0) sesudah perlakuan (post-test) ialah 568,82 $\pm 9,558$ $\mathrm{U} / \mathrm{mg}$ protein, sedangkan pada kelompok 
perlakuan $(\mathrm{P} 1)$ ialah $588,37 \pm 10,629 \mathrm{U} / \mathrm{mg}$ protein $(P<0,01)$ (Tabel 1). Hasil penelitian ini didukung oleh beberapa penelitian terdahulu. Verma et al. ${ }^{16}$ menunjukkan bahwa pemberian ekstrak etanol seluruh bagian tumbuhan pisang raja (Musa $x$ paradisiaca) dapat mencegah kerusakan oksidatif hati yang diinduksi karbon tetraklorida $\left(\mathrm{CCl}_{4}\right)$ dan meningkatkan kadar antioksidan enzimatik SOD dan katalase serta menurunkan peroksidasi lipid; semakin tinggi dosis ekstrak yang diberikan maka efektifitas antioksidannya semakin meningkat.

Tabel 1. Perbandingan kadar SOD antar kelompok

\begin{tabular}{lccccc}
\hline \multicolumn{1}{c}{ Kelompok } & $\mathbf{N}$ & $\begin{array}{c}\text { Rerata } \\
\text { (U/mg protein) }\end{array}$ & SB & $\boldsymbol{t}$ & $\boldsymbol{P}$ \\
\hline Kontrol (P0) & 18 & 568,82 & 9,558 & $-5,804$ & 0,00 \\
Perlakuan (P1) & 18 & 588,37 & 10,629 & \\
\hline
\end{tabular}

Penelitian oleh Goel et al. ${ }^{17}$ juga menunjukkan bahwa ekstrak pisang ( Musa sapientum var. paradisiaca) dapat mengurangi stres oksidatif pada lambung yang terinfeksi $H$. pylori dan meningkatkan aktivitas antioksidan endogen seperti SOD dan katalase. Hasil penelitian oleh Mallick et al. ${ }^{18}$ juga mendukung penelitian ini, yaitu pemberian ekstrak akar pisang (Musa paradisiaca) yang mengandung flavonoid dan fenol dapat meningkatkan kadar SOD pada jaringan testis tikus Wistar yang diinduksi diabetes. Hasil penelitian menunjukkan bahwa stres oksidatif pada plasma berkurang secara bermakna setelah memakan buah pisang tunggal pada manusia yang sehat kandungan antioksidan yang tinggi pada tanaman pisang. ${ }^{19}$ Aktivitas antioksidan juga dilaporkan pada ekstrak air kulit pisang dengan berbagai metode pemeriksaan. ${ }^{20}$ Terdapat penelitian yang melaporkan bahwa kandungan glikosida dan komponen monosakarida merupakan komponen utama yang bertanggung jawab untuk aktivitas antioksidan, ${ }^{21}$ namun penelitian independen lain melaporkan bahwa aktivitas anti-oksidan yang diekstrak dari $M$. paradisiaca pada tikus didominasi oleh kandungan flavonoid. ${ }^{22}$

Beberapa hasil penelitian menemukan bahwa flavonoid pada pisang meningkatkan aktivitas SOD dan katalase yang mungkin bertanggung jawab atas penurunan tingkat produk peroksidasi lipid seperti malondialdehid, hidroperoksida, dan diena terkonjugasi. $^{20,22}$ Kandungan flavonoid dapat meredam efek buruk radikal bebas dengan menghambat peroksidasi lipid melalui aktivasi peroksidase terhadap hemoglobin, yang merupakan antioksidan endogen (enzimatis) seperti SOD dan katalase. ${ }^{23}$ Peroksidase bermanfaat untuk mencegah penimbunan $\mathrm{H}_{2} \mathrm{O}_{2}$, yang keberadaannya menjadi berbahaya jika bersama-sama dengan $\mathrm{O}_{2} \bullet-$, karena dapat membentuk radikal $\bullet \mathrm{OH}$ yang merupakan radikal bebas yang paling reaktif dan paling berbahaya, yang dapat merusak membran sel dengan menyebabkan terputusnya asam lemak tidak jenuh. ${ }^{24}$ Kandungan flavonoid diketahui merupakan antioksidan pemutus rantai (chain breaking antioxidants) yang larut dalam lemak, yang bekerja pada membran sel, yang dapat memutus rantai peroksidasi lipid. ${ }^{25,26}$

Efek flavonoid terhadap ROS terjadi melalui dua mekanisme yaitu dengan menangkap radikal bebas/menetralisir dan meningkatkan antioksidan endogen seperti SOD. Peningkatan antioksidan endogen oleh flavonoid telah terbukti dalam penelitian in vitro melalui peningkatan faktor transkripsi Nrf2 yang meningkatkan ekspresi protein $\mathrm{HO}^{27}{ }^{27}$ Flavonoid dapat mengaktifkan ERK, JNK, dan P38, kemudian selanjutnya mengaktifkan Nrf2 sehingga terjadi peningkatan ekspresi gen antioksidan endogen. ${ }^{28}$

\section{SIMPULAN}

Berdasarkan hasil penelitian ini dapat disimpulkan bahwa pemberian ekstrak 
floret pisang raja (musa $x$ paradisiaca) dapat mencegah penurunan kadar super oksida dismutase pada hati mencit (Mus musculus) BALB/c dengan aktivitas fisik berlebih.

\section{DAFTAR PUSTAKAA}

1. Liochev SI. Which is the most significant cause of aging? Antioxidants (Basel). 2015;4(4):793-810.

2. Riddle DR. Brain Aging: Models, Methods, and Mechanisms. Boca Raton (FL): CRC Press/Taylor \& Francis, 2007.

3. Rahman T, Hosen I, Islam MMT, Shekhar HU. Oxidative stress and human health. Adv Biosci Biotechnol. 2012;3:997-1019.

4. Pingitore A, Lima GP, Mastorci F, Quinones A, Lervasi G, Vassalle C. Exercise and oxidative stress: potential effects of antioxidant dietary strategies in sports. Nutrition. 2015;31(7-8):91622.

5. El-Missiry MA. 2012. Antioxidant enzyme. Croatia: InTech. Available from: http://dx.doi.org/10.5772/2895

6. Chun KS, Kundu J, Kundu JK, Surh YJ. 2014. Targeting Nrf2-Keap1 signaling for chemoprevention of skin carcinogenesis with bioactive phytochemicals. Toxicol Lett. 2014;229(1):73-84.

7. WijayantoT, Dirvamena B, Ente $L$. Hubungan kekerabatan aksesi pisang kepok (Musa paradisiaca Formatypica) di Kabupaten Muna berdasarkan karakter morfologi dan penanda RAPD. J Agroteknos. 2013;3(3): 163-170.

8. Mahmood A, Ngah N, Omar MN. 2011. Phytochemicals constituent and antioxidant activities in Musa $\mathrm{x}$ Paradisiaca flower. Eur J Sci Res. 2011;66(2):311-8.

9. Binekada MC. Pelatihan fisik berlebih menurunkan konsentrasi dan motilitas spermatozoa mencit [Tesis]. Denpasar: Universitas Udayana; 2002.

10. Vitariana. Pemberian ekstrak daun kayu manis menurunkan kadar isoprostane dalam urin tikus Wistar yang diberikan beban aktivitas fisik berlebih maksimal [Tesis]. Denpasar: Program Studi Magister Biomedik Universitas Udayana; 2011.
11. Baraas F. Kardiomolekuler, Radikal Bebas, Disfungsi Endotel, Aterosklerosis, Antioksidan, Latihan Fisik dan Rehabilitasi Jantung. Jakarta: Yayasan Kardia Ikratama, 2006; p. 266-95.

12. McArdle WD. Essentials of Exercise Physiology (3rd ed). NewYork: Lippincott William Wilkins, 2006. p. 642.

13. Schneider CD, Oliveira AR. Oxygen free radicals and exercise: mechanisms of syhthesis and adaptation to the physical training. Rev Bras Med Esporte. 2004;10(4):314-8.

14. Cooper KH. Sehat Tanpa Obat. Empat Langkah Revolusi Antioksidan yang Mengubah Hidup Anda (Cetakan Pertama). Bandung: Penerbit Kaifa, 2001; p. 73-89.

15. Stanojevic D, Jakovljevic V, Barudzic N, Zivkovic V, Srejovic I, Parezanovic Ilic K, et al. Overtraining does not induce oxidative stress and inflammation in blood and heart of rats. Physiol Res. 2016;65(1):81-90.

16. Verma $P$, Paswan SK, Verma S, Singh SP, Rao CV, Shrivastva S, et al. Assessment of hepatoprotective activity of Musa paradisica Linn. Whole plant extract against carbon tetrachloride induced hepatotoxicity in wistar rats. IJPSR. 2017;8(1):126-31.

17. Goel RK, Sairam K, Rao CV. Role of gastric antioxidant and anti- $H$. pylori activities in antiulcerogenic activity of plantain banana (Musa sapientum var. paradisiac). IJEB. 2001;39:719-22.

18. Mallick C, Bera TK, Ali KM, Chatterjee K, Ghosh D. Diabetes-induced testicular disorders Vis-à-vis germ cell apoptosis in albino rat: remedial effect of hexane fraction of root of Musa paradisiaca and leaf of Coccinia indica. Journal of Health Science. 2010;56(6):641-54.

19. Yin X, Quan J, Kanazawa T. Banana prevents plasma oxidative stress in healthy individuals. Plant Foods Hum. Nutr. 2008;63:71-6.

20. Imam MZ, Akter S. Musa paradisiaca L. and Musa sapientum L.: A phytochemical and pharmacological review. J App Pharm Sci. 2011;1(5): 14-20.

21. Mokbel MS, Hashinaga F. Antibacterial and 
antioxidant activities of banana (Musa, AAA cv. Cavendish) fruits peel. Am J Biochem Biotechnol. 2005;1(3):12531.

22. Vijayakumar S, Presannakumar G, Vijayalakshmi NR. Investigations on the effect of flavonoids from banana, Musa paradisiaca L. on lipid metabolism in rats. J Diet Suppl. 2008;6(2):111-23.

23. Mot AC, Damian G, Sarbu C, Silaghi DR. Redox reactivity in propolis: direct detection of free radicals in basic medium and interaction with hemoglobin. Journal Medicine Food. 2009;14(6):267-74.

24. Cadenas E, Packer L. Vitamin C: from molecular action to optimum intake. In: Cadenas E, Packer L, editors. Handbook of Antioxidants (2nd ed). California: Marcel Dekker, Inc, 2002; p. 128-34.

25. Murray RK, Granner DK, Mayes PA,
Rodwell VW. Harper's Biochemistry (25th ed). USA: Mc Graw-Hill, 2000; p.124, 156-157, 618-620.

26. Milner JA. 2002. New insights into the mechanism of action of antioxidants. Dietary Reference Intake, Foods and Nutrition Board. Natl Acad Press. [cited 2016 Dec 23]. Available from : http//ods.od.nih.gov/nems/conference/o da2002/milner-pdf.

27. Maher P, Hanneken A. Flavonoids protect retinal ganglion cells from oxidative stress-induced death. Invest Ophthalmol Vis Sci. 2005;46(12):4796803.

28. Huang CS, Lii CK, Lin AH, Yeh YW, Yao HT, Li CC, et al. Protection by chrysin, apigenin, and luteolin against oxidative stress is mediated by the Nrf2-dependent up-regulation of heme oxygenase 1 and glutamate cysteine ligase in rat primary hepatocytes. Arch Toxicol. 2013;87:167-78. 